\title{
客船以外での一般乗船者向けの案内放送に関する研究
}

\author{
下薗 夏海 ${ }^{1} \cdot$ 吉田 南穂子 ${ }^{2}$ ・小島 智恵 ${ }^{2}$ ・鈴木 $\quad$ 治 $^{2}$
}

\section{A Study of the Guidance Announcements for General Passengers with the Exception of Passenger Ships}

\author{
Natsumi SHIMOZONO, Nahoko YOSHIDA,
}

\section{Chie KOJIMA and Osamu SUZUKI}

\begin{abstract}
There are many ships open to the public during port festivals. The training ship "Toba Maru" (gross tonnage $244 \mathrm{t}$, length $40 \mathrm{~m}$ ) has been open to the public every year for port festivals since 1997. However, guidance announcements have never been put into effect on the ship. The authors researched the guidance announcements on public transportation and verified the announcement system which is easy to use on ships. The announcements on public transportation are made by automatic broadcasting equipment, or are manually broadcast by the crew. The announcements of the automatic method are spoken slower than those of the manual. The authors proposed that the announcement system consists of a public address system and an audio playback device. A CD player is easiest to use for mariners. It is presumed necessary to announce slowly, and that technical words in the announcement script be simple for the onboard environment such as strong winds and loud noises. The onboard crew are able to use these methods. However, officers still have problems communicating accurate information in their announcements. Effective, good announcements are expected to improve communication within a ship.
\end{abstract}

Keywords : information support, opening to the public, guide information, announcement キーワード : 情報支援、一般公開、案内放送、アナウンス

\section{1. はじめに}

近年、客船以外の船舶でもその船舶や所属する団 体の紹介をする PR 活動のため船内の見学が出来る 一般公開や、その航海に参加できる体験航海が多く 行われている。これらの船舶は乗客の乗船を目的と しており、乗組員が乗客に対して徹底的なサービス を心掛けている客船 ${ }^{(1)}$ とは異なり、一般の人の乗船 を目的としていないため様々な手法による船内の案 内 ${ }^{(2)}$ が求められる。しかし、その一方で船内での案 内放送は放送原稿の作成、要員の確保など十分な準 備が必要であり実施されていない船舶もある。
客船以外の船舶の一般への公開の実状をWeb で 調査したところ、各商船系の学校の練習船 ${ }^{(3)}$ や巡視 船、護衛艦や調查船等、多くの場所や船で行われて いた。主に「一般公開」と呼ばれる、停泊中の船内 見学が行われており、乗船させて短い航海を行う「体 験航海」を行っている船舶もあった。

鳥羽商船高等専門学校の練習船鳥羽丸 (全長 $40 \mathrm{~m}$, 244 総トン) は年に数回、PR 活動のため三重県鳥羽 市の近くの港である名古屋港や四日市港で一般公開 (4)や、体験航海を行っており学生や船員・教員が船 内の各所に立ち見学者に直接、船内案内や注意喚起 
をしている。一般公開時の案内放送の実施は、その 船舶での裁量に任されている。案内放送を実施でき れば、より PR の効果の向上が見込める。そこで、本 研究では案内放送の指針を得るために他の交通機関 の案内放送を調查した後、鳥羽丸を含む客船以外の 船舶で利用できる手法について調查、検証すること にした。

\section{2. 各交通機関の案内放送}

客船以外の船舶では案内放送の実施例が少なく、 また指針となる文献等も少ないため乗客向けの案内 放送を実施している船舶、鉄道、航空機、バスでの 特徵を実際に有償の乗客として利用・調査をするこ とで指針を得ることとした。なお、航空機の非常設 備に関する放送やアナウンスは調査対象外とした。

\section{1 案内放送の特徵}

表1は調查を行った交通機関毎の案内放送をまと めたものである。放送内容は行き先や乗り換え案内、 注意喚起が多く次の停車駅等の強調したい用語は繰 り返されているほか、地名などはゆっくり話すなど の工夫がされていた。鉄道では、マイクによる放送 の他に車掌が車両を巡回し乗客に対して直接、次の 停車駅等の案内を行っていた。使用される用語は一 般的なものであり、標準語が使用されていた。使用 言語は乗員による放送は全て日本語のみであったが、 航空機のみ英語でも放送されていた。自動放送は日 本語のみ、もしくは日本語と英語の 2 ケ国語が多く、 都市部では英語の他に中国語や韓国語、スペイン語 等も使用されていた。

\section{2 案内放送の話速}

案内放送には乗員による放送と、音声が録音され て適宜再生される自動放送があった。自動放送は、 鉄道では定められた場所や間隔で放送され、バスで は乗員がボタンを押すことで放送されていた。放送 で1分間に話す速度（以下、話速）は、乗員による放 送と自動放送では話速が異なっており自動放送のほ うが遅かった。乗員による放送の平均話速は、472 文字/分で早い傾向があり、特に電車では出発時刻が 近づくほどより早くなった。自動放送の平均話速は、 338文字/分で全て女声であった。乗員による放送は 臨場感があり、注意喚起の意味はあるが場合によっ ては話速が早いため聞き取りづらいこともあった。
一方で、自動放送は走行中で騒音の中でも聞き取り やすいことがわかった。

\section{3 客船以外の船舶での適用}

通常、船舶には、船内各所一放送を行うための装 置として船内指令装置や放送装置、操船指令装置と いった放送設備があるため案内放送にはこれを利用 する。これらの放送設備は、船内各所にスピーカが 設置されているため船内外の主要箇所での放送が可 能である。また、マイクを利用することを想定して いるが、他の機器の接続も可能となっている。

表 1 各交通機関の案内放送の話速

\begin{tabular}{|l|c|c|}
\hline \multirow{2}{*}{ 種類 } & \multicolumn{2}{|c|}{ 文字/分 } \\
\cline { 2 - 3 } & 乗員 & 自動 \\
\hline 鳥羽市営定期船（佐田浜〜菅島） & - & 340 \\
\hline 津エアポートライン & 582 & 356 \\
\hline 伊勢湾フェリー & 312 & - \\
\hline 名古屋臨海高速鉄道あおなみ線 & - & 360 \\
\hline JR 東海関西本線（名古屋～四日市） & 570 & 370 \\
\hline 名古屋市営地下鉄名城線（市役所〜栄) & 560 & 340 \\
\hline 名古屋鉄道（太田川〜尾張横須賀） & 485 & 275 \\
\hline 近畿日本鉄道（宇治山田～伊勢市） & 368 & - \\
\hline ANA 航空機（函館〜伊丹） & 444 & - \\
\hline JAL 航空機（伊丹〜函館） & 396 & - \\
\hline 鳥羽市営バス（商船学校前～鳥羽） & - & 330 \\
\hline 三重交通バス（津〜津なぎさまち） & 528 & 326 \\
\hline 豊橋鉄道バス（伊良湖岬〜豊橋） & - & 342 \\
\hline
\end{tabular}

\section{3. 案内放送に関する関係法令}

案内放送の実施にあたり、船内における案内放送 に関する法律を調查した。調查した法律は船員法、 船舶設備規程、船舶救命設備規則、海上運送法、SOLAS 条約 ${ }^{(5)}$ である。この中で、SOLAS 条約に、「全ての旅 客船は、船内放送装置を備えなければならない。」、

「船内放送装置は、周辺の騒音より明瞭に聞こえな ければならない。」と規定されているが、案内放送の 実施方法に関する規定は特にないことが分かった。 また、船内の騒音に関しては船舶設備規程で 1,600 トン以上の船舶には防音装置の設置義務が規定され ているが、それ以外の船舶では規定されていないこ とがわかった。交通機関の案内放送に関して高齢者、 身体障害者等の移動等の円滑化の促進に関する法律 を調査したところ、バスや船舶、航空機では運行に 関する情報を音声により提供するための設備の設置 は義務付けられているが、放送の仕方に関寸る規程 は自明であるためか特に定められていないことがわ かった。 


\section{4. 鳥羽丸での実証}

交通機関の案内放送の調查結果から、客船以外で の船舶でも実施方法を工夫すれば案内放送が可能で あることがわかった。そこで、鳥羽丸で実施可能な 方法を検証するため一般公開や体験航海で案内放送 を実施することにした。

\section{1 鳥羽丸の放送設備}

鳥羽丸にはカセットテーププレイヤを搭載した 船内指令装置（日本舶用エレクトロニクス製 OHE-3177）があり、これを利用して乗船者向けの案 内放送を行うこととした。数回の一般公開で利用後、 カセットテーププレイヤが故障したため、さらに汎 用性および利便性を高めるため、PC 等の外部の機器 の接続や、USBメモリやSD カード、Bluetooth が利 用可能な CD プレイヤ (Pioneer 製 DEH-970) に換装 した。これらの機器は、汎用的なものであり、多く の船舶でも類似の機能を有していると考える。

\section{2 原稿の作成}

船内の乗船者に伝えたい情報を確実に伝えるため、 原稿を予作成することとした。内容は、船舶の紹 介の他、注意㬇起、救命設備の位置等とした。表 2 に体験航海時に利用した「注意喚起」の原稿を示す。 船内と船外では風や推進機関の音の影響が異なり放 送が聞き取りづらいこともあるため、より一般的な 用語や標準語 ${ }^{(6)}$ を使用寸る必要があり、表 3 は鳥羽 丸での言い換えた用語の例である。乗員は普段から 専門用語やその船のみで伝わる特殊用語を使用して おり、どの用語が一般の人が理解しづらいのか判断 が難しい。そこで言い換え後の用語は、船のことを ほとんど知らない一般の人の意見を参考として作成 した。

\section{3 鳥羽丸での実施の問題点}

図 1 は、学生が放送設備のマイクを用いて案内放 送を行った時の様子である。本研究に取り組んだ初 期のころ、話者に特に練習や話し方の指示はせず原 稿を渡して読んでもらったところ、原稿の読み間違 いが多く、そして、声量の調節が難しく、話速が不 均一となり聞き取りにくいという問題があった。

\section{4 話し方}

案内放送に慣れない人が放送をすると、抑揚やア クセントが不適切で聞き取りづらいことがある。文
献 (7) 参考に標準語とし、話速やアクセントを定め た。そして、あらかじめ模範となる放送を何度か聞 いてもらう学習の機会を与えた。これらにより話速 は、ほぼ指定速度になりアクセントも標準的になる ことがわかった。また、発声方法を練習し聞き手が 情報を理解寸る間が必要なため ${ }^{(8)}$ 、専門用語や強調 したい単語の前には一呼吸置くように工夫した。

\section{5 話速}

鳥羽丸のような総トン数の小さい船舶では機関室 やその付近の場所で一部、騒音が大きい場所がある。 また、風等の影響により放送が聞き取りづらいこと があるため、全箇所で聞き取りやすいよう交通機関 の自動放送の平均話速より遅い 200～300 文字/分程 度で行った。

表 2 体験航海時の注意喚起の原稿

ご乗船の皆様にお願いします。この船は一般客 船とは異なり多くの段差が存在し、通路が狭く階 段が急になっています。移動の際には十分にお気 を付けください。この船は航行中に突然摇れる場 合がありますので、安全のため外で見学の方は転 落防止のため手すりにもたれず、また床にお座り にならないようにお願いします。

表 3 鳥羽丸の場合の言い換えの例

\begin{tabular}{|l|l|}
\hline 専門用語 & 一般用語 \\
\hline \hline 船橋 & 操縦室 \\
\hline 救命胴衣 & 救命具 \\
\hline ライフラフト & 救命ボート \\
\hline 両舷 & 両側 \\
\hline 乗組員 & 船内職員 \\
\hline ハンドレール & 手寸り \\
\hline 甲板 & 床 \\
\hline 上甲板 & 操縦室の 2 階下 \\
\hline 離岸 & 出発 \\
\hline 着岸 & 到着 \\
\hline 本船 & この船 \\
\hline 船酔い & 気分が優れない \\
\hline ノット & 時速 \\
\hline ホーサー & ロープ \\
\hline 舷梯 & 入口階段 \\
\hline 船速 & 速度 \\
\hline デッキ(甲板) & 階 \\
\hline
\end{tabular}




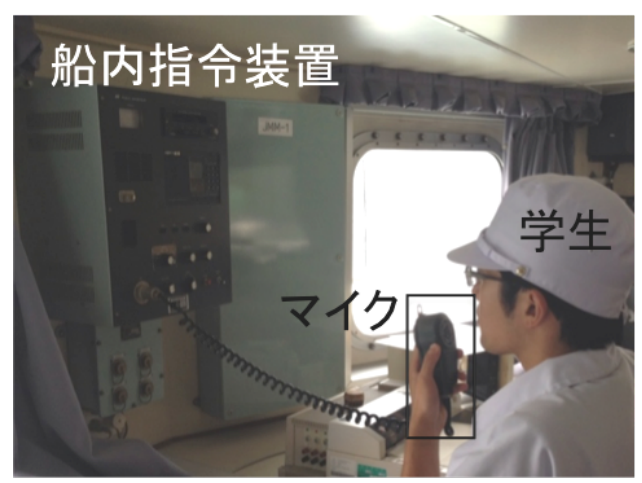

図 1 学生が案内放送を行っている様子

\section{5. 案内放送の録音}

鳥羽丸の一般公開の場合は見学の順路で見学す ると見学時間はおおよそ20３0 分である。その間、 案内放送を 2 3 回聞くことが出来るようにしたか ったため放送の間隔は 5〜10 分間隔とした。また、 体験航海時には仮に 1 時間半の航海であれば 15〜20 分間隔となる。繰り返し聞くことで、船内にいる乗 員や見学者が不快にならないように工夫が必要であ り、本研究ではその間隔を一定ではない放送も実施 した（不定間隔再生）。鳥羽丸のように乗員が 9 名 と少ない船舶では案内放送要員の確保が難しい。こ れらの一定間隔での放送や、不正確・不明瞭な放送 の防止や乗組員の少ない船舶を想定すると、事前に 録音した音声を放送する手段が必要であることがわ かった。

\section{1 放送に対する意識調査}

客船以外の船舶の乗員は乗員向けの通話や放送 は行うが、乗客を対象とした放送の経験はない者が 多く、案内放送の実施は不慣れであると考える。鳥 羽商船高等専門学校商船学科の学生と船員 - 教員各 10 名を対象に放送に対する意識調査を行った。表 4 はその調査結果を示す。マイク放送とは、原稿を用 意せずに行う業務連絡などのものであり、案内放送 とは原稿を用意して乗客を対象に行うものとする。 調査結果から、普段から放送を行っている者は自信 があるという回答が多かったが、経験のない者は苦 手意識があることがわかった。また、原稿を用意し ていれば安心感があるという回答も多かった。この ことから、定型文の案内放送は録音して放送する手 段の採用でより確実な情報の提供が可能になる。

\section{2 放送設備との接続と録音}

案内放送は、各再生機器と CD プレイヤを図 2 の
ように接続することで、音声の再生が可能である。 どの方法においても、初めに音声を準備する必要が あり今回は、スマートフォンのアプリケーションを 用いて、MP3 (MPeg layer 3) 形式で録音した。

\section{3 再生装置毎の特徴}

乗員が容易に自動放送を実施するため、いくつか の自動再生システム ${ }^{(9)}$ を提案した。表5は各再生方法 の特徵を示したものである。カセットテープは、定 間隔・不定間隔での再生が可能であり、簡単に誰で も使用可能であるが、現在、再生するためのカセッ トテーププレイヤを装備している船舶は少ないと考 えられる。プログラムの特徵についての詳細は後述 する。CDは、再生が容易であり、カセットテープと 同様に定間隔・不定間隔での再生が可能である。CD プレイヤを介した放送設備とPCやスマートフォンと の無線接続も容易であることは確認できたが、スマ 一トフォンは不特定多数の人が出入りする一般公開 時には盗難の恐れがあるため無人での利用が難しく、 電源の確保の面でも問題があることがわかった。

\section{4 案内放送作成手順}

図3に各案内放送の作成手順を示す。音声はICレコ 一ダ等でデジタル化し録音する。その後、PC上のソ フトを用いて再生間隔を編集し、MP3化、およびCD 化した。カセットテープへはCDから録音した。また、 PC等を利用して、案内放送を録音したMP3ファイルを 放送する仕組みがある。なお、PC等と放送設備との 接続は、CD同様に有線による接続の他、Bluetooth による無線接続が考えられる。

表 4 放送の実施に対する調査結果

\begin{tabular}{|l|c|c|c|c|}
\hline & \multicolumn{2}{|c|}{ 学生（名） } & \multicolumn{2}{c|}{ 船員・教員 (名) } \\
\cline { 2 - 5 } & はい & いいえ & はい & いいえ \\
\hline マイク放送に自信がある & 2 & 8 & 5 & 5 \\
\hline 案内放送に自信がある & 4 & 6 & 6 & 4 \\
\hline
\end{tabular}




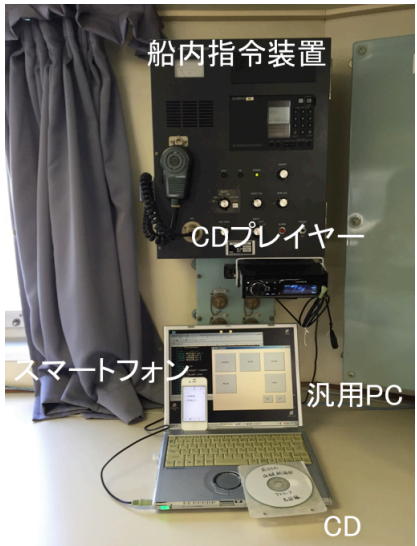

図 2 各再生用機器と接続した船内指令装置

表 5 各再生方法の特徵

\begin{tabular}{|c|c|c|c|c|c|}
\hline & \multirow{2}{*}{$\begin{array}{l}\text { カセット } \\
\text { テープ }\end{array}$} & \multirow[t]{2}{*}{$\mathrm{CD}$} & \multirow{2}{*}{$\begin{array}{c}\text { プロ } \\
\text { グラ } \\
\text { ム }\end{array}$} & \multicolumn{2}{|c|}{$\begin{array}{c}\mathrm{PC} \cdot \text { スマートフォ } \\
\text { ン }\end{array}$} \\
\hline & & & & $\begin{array}{c}\text { ケーブ } \\
\text { ル }\end{array}$ & $\begin{array}{l}\text { 無線 } \\
\end{array}$ \\
\hline 作成 & $\Delta$ & $\triangle$ & $\triangle$ & - & - \\
\hline 再生 & (2) & (2) & $\bigcirc$ & $\bigcirc$ & 0 \\
\hline 定間隔 & $\bigcirc$ & $\bigcirc$ & $\bigcirc$ & $x$ & $x$ \\
\hline 不定間隔 & $\triangle$ & $\triangle$ & $\bigcirc$ & $\bar{x}$ & $\bar{x}$ \\
\hline 連続再生 & $\bigcirc$ & 0 & 0 & $\bigcirc$ & 0 \\
\hline 利便性 & 0 & (a) & $\bigcirc$ & $\triangle$ & $\triangle$ \\
\hline
\end{tabular}

（）：非常に使いや寸い $\bigcirc$ : 使いや寸い $\triangle$ : 使いづらい

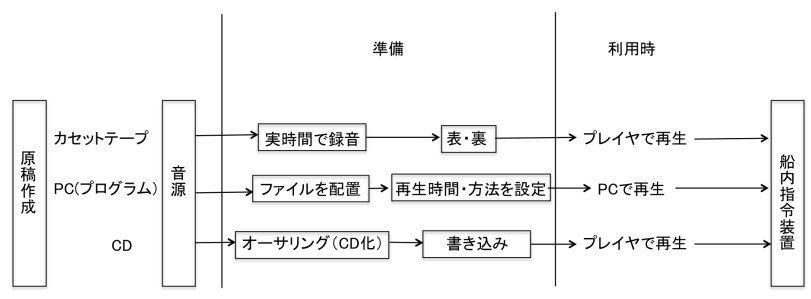

図 3 案内放送の作成手順

\section{6. 案内放送自動再生システムの開発}

案内放送を頻繁に使用しないのであれば、一度作 成すれば長期的に使用できるCDが向いているが、頻 繁に使用し、状況に合わせて様々な種類の音声を必 要とする際には効率の良い方法とは言えない。そこ で汎用のPCで開発でき、その開発環境が無料である HSP (Hot Soup Processor) (10) を使用して案内放送 自動放送プログラムを試作した。この案内放送自動 再生システムの機能、特徵を表6に示す。また、図4 は、作成したプログラムの実行画面を示したもので ある。タッチパネルでの利用も想定し、機能を示す ボタンを大型にし、機能は一度だけ再生する方法 (単 独再生）や指定された間隔での再生（定間隔再生、 不定間隔再生）が出来る他、プログラムの再作成も 可能である。
図5にCD とプログラムの再生間隔の仕組みを示す。 $\mathrm{CD} 、$ プログラムとも定間隔再生は可能であるが、不 定間隔再生の場合、CDは作成時に設定した固定の間 隔でしか再生できないがプログラムは間隔に幅を持 たすことができ、この間隔は指定した時間内で再生 する度に変化する。また、画面を見ながら操作が出 来るため放送する音声の選択も容易で使用しやすい ように作成した。なお、ネットワーク環境が不要で あるため、どの船舶でも使用できるように配慮した。

表 6 案内放送自動再生システムの機能

\begin{tabular}{|c|c|}
\hline 構成 & $\begin{array}{l}\text { ソフトをインストール } \rightarrow \mathrm{PC} \text { でプログ } \\
\text { ラム作成 } \rightarrow \text { 放送設備と接続 } \rightarrow \text { 再生 }\end{array}$ \\
\hline \multirow[t]{5}{*}{ 機能 } & 単独再生 \\
\hline & 連続再生 \\
\hline & 定間隔再生 \\
\hline & 不定間隔再生 \\
\hline & 停止 \\
\hline 特徵 & $\begin{array}{ll}\cdot & \text { 汎用 PC で作成可能 } \\
\cdot & \text { 何度でも再作成が可能であり、音 } \\
& \text { 声や再生間隔の変更が容易 } \\
\cdot & \text { 画面を見ながらの操作が可能 } \\
\cdot & \text { スダンドアロン動作可 }\end{array}$ \\
\hline
\end{tabular}

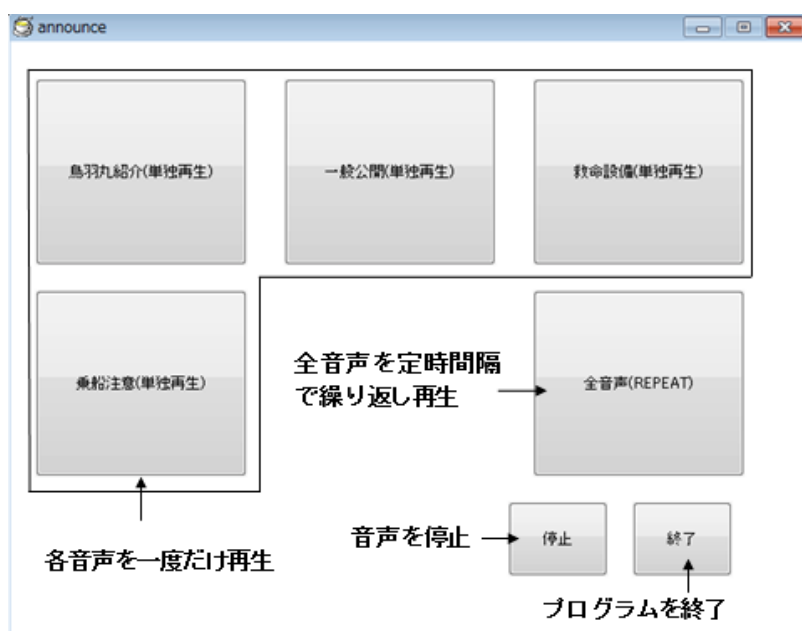

図 4 案内放送自動再生システムの実行画面 


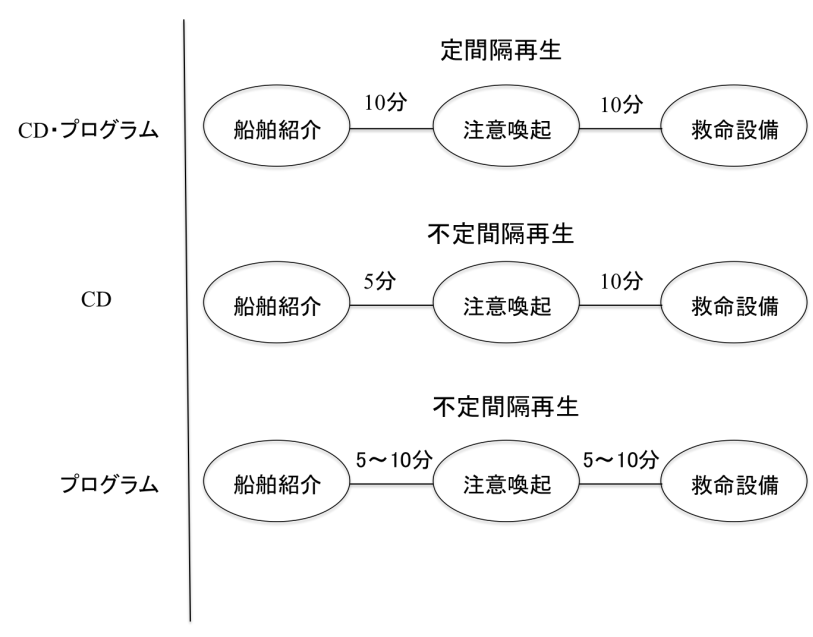

図 5 CD とプログラムの再生間隔の仕組み

\section{7. 評価と発展}

本研究で提案する案内放送とその手法について、 見学者と乗員である学生や船員. 教員を対象に評価 する。またこの成果の発展的な利用のため、作成し た原稿および音声データの提供について提案する。

\section{1 案内放送の効果}

作成した案内放送の効果を確認するため、名古屋 港や四日市港での一般公開や 1 時間半程度の体験航 海、スナメリ観察をするイベントでの半日の体験航 海で乗船者に調査目的を伝えて聞き取り調査を行っ た。案内放送を聞いていた人は半数で、内容まで聞 き取っている人は 2 割であった。また、話速は 220 文字/分（女声）、250 文字/分（女声）、310 文字/ 分 (男声) のいずれも聞き取りやすいという意見を 多く得た。男声よりも女声の方が聞き取りやすいと いう意見が多く、練習船に限ることであるが、男子 学生が多い中で女子学生の声が聞こえると注目され る傾向があることがわかった。また、案内放送の必 要性について聞いたところ、必要であるとの肯定的 な意見が多かった。

\section{2 放送手段の評価}

これまで客船以外の船舶で案内放送に利用可能な 放送手段を開発したが、どの手法が乗員にとって簡 単に実施可能なものか不明である。そこで、本研究 で提案したいくつかの手法の中からどの手法が簡単 に作成・再生が可能か判断するため著者らが鳥羽商 船高等専門学校商船学科の学生と船員 - 教員各 10 名（全 20 名）を対象に目的を伝えてから聞き取り調 査を行った。表 7 にその調査内容と結果を示す。調
査結果から、多くの者がカセットテープの録音や MP3 の編集、CD の作成は出来ないため事前にこれら が出来る者が準備し、放送する方法が良いと考えら れる。プログラムによる放送は、大多数の者が作成 方法が分からず、使ったことがないため操作も不安 だという意見が多かった。一方、以前から鳥羽丸で は業務で CD を利用しているため、使い慣れており、 数種類の手段のうち最も CD が簡単に操作可能だと いう意見が多かった。このことから、鳥羽丸では著 者らが事前に案内放送用の CD を作成しておき、当日 に乗員が既存の放送設備を用いて再生する方法を採 用した。この方法は学生や船員・教員共に全員が特 別な説明を要せず、問題なく実施することが出来た。 これは、船内に設置されているものを使用すること で放送機器の準備が不要であり、普段使用している 機器であるため使用法を新たに覚える必要がなかっ たからだと考える。

\section{3 案内放送コンテンツ提供の仕組み}

鳥羽丸では CD やプログラムによる案内放送がで きるようになった。しかし、多くの船舶で同様なシ ステムを導入できるわけではない。そこで、本研究 の発展としてどの船舶においても比較的、導入が容 易な仕組みを考えた。図 6 は、他の船舶向け案内放 送コンテンツの提供の仕組みを図示したものである。 案内放送を作成する段階で手間がかかるのは、案内 原稿の作成と音声の準備とシステム化である。この ために著者らが一般的な案内放送の原稿と、案内放 送の音声データを作成し、それを配布することとし た。著者らが案内音声をMP3 形式で録音し、その音 声ファイルをWeb page 上に置く。各船舶では、Web page から音声をダウンロードし、必要形式に加工、 必要があれば編集して使用するものである。例えば、 システム化が難しい船舶では、音声データを必要な 時間間隔に配置した CD 形式で利用し、リピート再生 で対応する。なお、放送設備に適切な再生機器が設 置できないまたは接続できない船でも公開している 原稿と音声を参考に何度か練習することで適切な案 内放送の実施が可能となる。執筆時点の上記の準備 された原稿と音声データは、下記の Web page からダ ウンロードが可能である。

http://www. ship. toba-cmt. ac. jp/announce/ 
表 7 放送の作成と再生方法の意識調査

\begin{tabular}{|l|c|c|c|c|}
\hline & \multicolumn{2}{|c|}{ 学生（名） } & \multicolumn{2}{c|}{ 船員・教員 (名) } \\
\cline { 2 - 5 } & はい & いいえ & はい & いいえ \\
\hline $\begin{array}{l}\text { カセットテープでの録音が } \\
\text { できる }\end{array}$ & 4 & 6 & 9 & 1 \\
\hline MP3の音楽の編集ができる & 3 & 7 & 3 & 7 \\
\hline CDの作成ができる & 3 & 7 & 8 & 2 \\
\hline $\begin{array}{l}\text { カセットテープの再生がで } \\
\text { きる }\end{array}$ & 9 & 1 & 10 & 0 \\
\hline MP3の再生ができる & 9 & 1 & 10 & 0 \\
\hline CDの再生ができる & 10 & 0 & 10 & 0 \\
\hline $\begin{array}{l}\text { PCでの MP3やCDの再生が } \\
\text { できる }\end{array}$ & 10 & 0 & 9 & 1 \\
\hline $\begin{array}{l}\text { PC で音声を扱ったプログラ } \\
\text { ミングができる }\end{array}$ & 3 & 7 & 1 & 9 \\
\hline
\end{tabular}

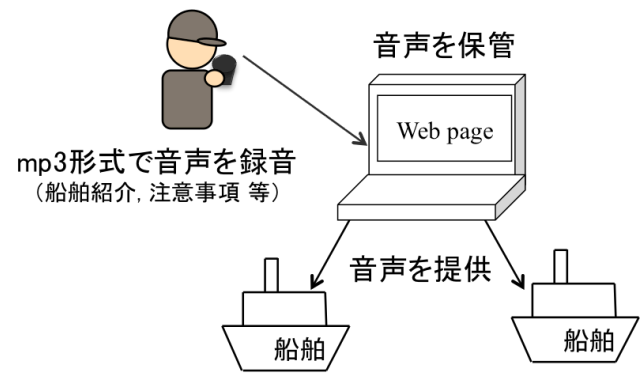

図 6 船舶向け案内放送提供システムの構成図

\section{8. 考察}

案内放送に不慣れな乗員は早口になりやすく原稿 の読み間違いにより結果として不正確・不明瞭な放 送になってしまうという問題点がある。これに対し て放送前に数回、練習寸れば案内放送に利用できる レベルとなることがわかった。また、練習時に良好 な読み上げを録音し一般公開時に利用すれば、当日 に乗員が放送することがなく、より正確な情報の伝 達が可能になった。

聞き取りやすい案内放送を検討し工夫していく中 で、いくつか話速を設定して練習していたところ最 もアクセントの位置に注意し正確な放送が可能だっ た 250 文字/分に設定し、再度録音して一般公開等で 利用したところ見学者および乗員から問題ないと評 価され、また、読み上げるのにも容易であるのでこ の話速は船内の案内放送の一つの指針となる。

本研究で検討した CD や PC による自動放送は多く の船舶に設置されている放送設備に接続すれば可能 なので、特殊な機器を必要とせずに実施でき本研究 の目的の客船以外での船舶で利用が望める。また、 機器の利便性については実際に乗員や学生に実際に 操作してもらったところ、CD が普及しているせいか
多くの人が CD を選択し、簡便に利用してもらえた。 一方、PC と試作したプログラムを利用する方法は PC の操作とプログラム作成の両知識が必要であるが、 知識のある者にとってはプログラムソースの提供が あれば、他の手法に比べ作成者の意思によって自由 自在に放送が実施できる長所がある。そのため、プ ログラム作成をほとんど行わない乗員には、不要と いう意見が多かった。

交通機関の自動案内放送がすべて女声だったよう に、一般的には放送は女性が良いというイメージが ある。元々、女性が少ない船舶で案内放送を女性の 担当にすると業務が固定化され、他の業務の遂行に 支障がでる恐れがある。しかし、女声を採用する場 合にも案内放送であれば事前に録音にすることで対 応できる。また、放送原稿をあらかじめ練習した上 で、男性（学生）により録音したものを案内放送と して放送して聞き取り調査をしたところ、男声でも 特に問題がないことがわかった。

一般公開時の聞き取り調查で最も聞き取りをした 割合が高かったのは名古屋港で、案内放送に気づい た人が 9 割、内容まで聞き取っていた人が 4 割であ った。このことは案内放送が PR の手段の一つである ことを意味している。特に、乗員や案内する学生が 少ない鳥羽丸のような小型の船舶では乗客に対して 直接的な説明が十分に出来ないことから、案内放送 を聞くことができた乗客には概ね好評であった。以 上のことから、筆者らが提案した放送手法は他の船 舶でも有効であることが想像でき、より多くの船舶 で実施可能だと考える。

\section{9. おわりに}

本研究では、外注や十分な練習や準備が必要であ ると思われている案内放送について、乗員が少ない 船舶での利用を想定して、鳥羽丸での実装方法につ いて検討を行った。まず公共交通機関での実施状況 を調査、放送原稿の作成や話速に工夫が必要である ことがわかった。PC とプログラムによる案内自動放 送システムを試作し利用したところ不定間隔再生が 実施でき、また、CD に記録する方法によっては類似 な仕組を提供できることも確認した。なお、鳥羽丸 では CD による案内放送が研究終了後も継続して行 われており実用的であることを確認できた。他の船 舶でも放送設備は鳥羽丸同様のものが設置されてお り、CD であれば利用経験者が多く乗組員の負担には ならない。また乗組員数が 9 人と少ない鳥羽丸で実 
施が出来たため、もっと乗組員数が多いと考えられ る他の船舶では今回提案した話し方や放送手法、話 速や用語の言い換え等を工夫し練習することで、放 送に慣れていない人でもこの指針を応用した様々な 利用が期待できる。また、鳥羽丸以外での利用を想 定し、あらかじめどのような船舶でも利用可能な原 稿を録音したファイルを作成し、配布寸るために Web page 上で公開している。

案内放送の効果を理解した上で適切に実施すれば PR 活動のみならず船内での安全確保にも有効的で あると考える。今後は、航行中の船内外の騒音を測 定するなどして、各場所・状況に合わせた話速等に ついても検討したい。

\section{謝辞}

本研究は各交通機関の案内放送を参考とさせて 頂きました。本研究のデータ収集にご協力頂いた鳥 羽商船高等専門学校第 42 期の鳩山勇太様、第 43 期 の杉野士様、山下諒也様、また、調查にあたりご協 力を頂いた練習船鳥羽丸、商船学科および海事シス テム学専攻・生産システム工学専攻の学生そして、 教員の皆様に感謝致します。

\section{参考文献}

(1) 斎藤茂太: 船旅 $の$ 招待, PHP 研究所, pp. 123-126, 1997.

（2）杉野士 : 船内公開中の対応と安全確保のための 手法と提案, 日本航海学会誌, 第 191 号, pp. 90, 2015. 1.

（3）矢野吉治, 古莊雅夫 : 大学統合に伴う練習船機 能の変遷と評価, 日本航海学会論文集, 第 120 号, pp. 175-181，2009.3.

（4）鈴木治, 嶋岡芳弘：校内練習船と小艇による学 校紹介ーアンケートによる都市での船内一般 公開の効果, 日本航海学会誌, 第 143 号, pp. 172-179, 2000.3.

（5）国土交通省海事局安全政策課/監修：2014 年海 上人命安全条約 : 英和対訳, 海文堂出版, 2014 .

（6）蛇蔵, 海野凪子：日本人の知らない日本語, 株 式会社メディアファクトリー, 2009.

（7）日本放送協会：日本語発音アクセント辞典, 日 本放送出版協会, 1985.

（8） NHK アナウンス・セミナー編集委員会：NHK ア ナウンス・セミナー〜放送の現場から， pp. 114-117, NHK 出版, 2015.
（9）下薗夏海 : 客船以外の船舶を対象とした自動ア ナウンス装置の開発，電子情報通信学会 2015 年総合大会情報・システムソサエティ特別企画 学生ポスターセッション予稿集, p. ISS-P-74.

（10）大㭇有一郎：12 歳からはじめる HSP3.0わくわ くゲームプログラミング教室, 株式会社ラトル ズ, 2005. 